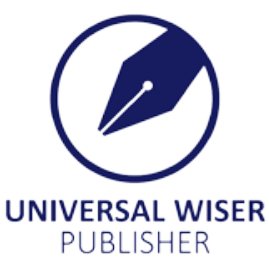

\title{
Mutual Funds in Emerging Markets; Prospects for Personal Financial Planning
}

\author{
David Doe Fiergbor \\ KBF Centre for International Studies, Ghana, P. O. Box GS 6040, Bortianor Sea View, Near Bojo Beach Resort, Accra, Ghana \\ Email: daviddoef@gmail.com
}

\begin{abstract}
Globalization has mammoth divergent opportunities that are distinct in promoting economic changes in emerging markets. These include but not limited to trade, foreign direct investments, short-term capital flows, knowledge and movements of labour. The prospects for financial sectors in emerging markets are great. The capital market opens up to new investments that tend to boost overall economic performances. The occurrence has been impelled by technical change, denationalization in emerging markets, the deregulation of the financial markets in industrial countries, increased in institutional investors in developed economies and macroeconomic and trade reforms have portrayed emerging markets more attractive. These amounted to various opportunities for the financial industry in emerging markets. With several natural resources such as oil and other mineral deposits, developing countries mostly within the African region emerge with positive fiscal projections for the capital market. Since some mutual funds invest in the capital and money markets, with proper personal financial planning, financial independence is eminent in the future for the lay investor. Mutual funds have the potential for higher yield with minimum risk as compared to some other risky investment schemes such as forex trading. Professional fund management and easy liquidity of assets are some advantages of investing in mutual funds. However, investment yields on mutual funds are not guaranteed as fund assets are invested in shares, bonds, and stocks which may have fluctuating market price movements. Randomly selected invested capitals were computed using simple expected future value formula. The result indicated higher returns potential on investments in mutual funds in the long run. It was therefore concluded that there is enormous opportunities for wealth creation in investing in mutual funds in emerging markets which is ideal for personal financial planning.
\end{abstract}

Keywords: mutual fund, emerging markets, globalisation

\section{Introduction}

The financial systems of the 21 st Century have been growing with speed, sophistication and becoming a more complex world ${ }^{[12]}$. The economic and social environments in which people take financial decisions have changed and this change is set to continue with the dynamic and ever-changing technology. Financial products and services have multiplied along with technology and other means of marketing them. ${ }^{[9]}$. Therefore, to be financially successful, there is the need for prudent personal financial planning in investment schemes like mutual funds that guarantee good returns over long periods of time.

A Mutual Fund is an investment pool that contains the savings of many investors with a common financial objective or goal ${ }^{[11]}$. Investors in mutual funds are called unit holders as the share of one's investment is the quantum of units purchased. The investment pool is diversified and invested in different investment instruments such as shares, bonds, debentures, and others. Income earned through these portfolios of investments and interests on invested capital is distributed proportionally to the unit holders of the fund according to the number of units purchased ${ }^{[19]}$. Mutual Fund is far the most appropriate investment scheme for the lay investor.

There are numerous prospects for the financial industry in emerging markets such as Ghana. With the discovery of oil and other mineral deposits that propelled Ghana as the gold hub in sub-Sahara Africa, there are positive economic prospects for the capital market ${ }^{[6]}$. Since some mutual funds invest in the capital and money markets, with proper personal financial planning, financial independence is eminent in the future for the lay investor.

This study aimed at exploring the viable potentials in investing in mutual funds in emerging markets and the prospects 
for personal financial planning. Careful analysis of data and results from some previous studies on mutual funds revealed the majority of potential investment opportunities in emerging markets. The industry is still underdeveloped and expanding markets have huge potential to take advantage of foreign investors investing in the capital markets to boost returns on investments. Randomly selected initial investment capitals were computed over varying periods of times to ascertain expected future yields. The results indicated incremental returns on invested capitals over time. This is ideal for ordinary investors in growing or emerging economies to seize the opportunities for personal financial planning.

\section{Literature review}

Emerging market are economies with fast increase process in relation to a rolling transition phase of high market potential. ${ }^{[24]}$. These markets have higher expandable capacities than developed markets to provide higher investment opportunities for higher returns. Simon opined certain key features of these markets which include; small economic size, low acceptance of foreign investors and unstable exchange rates with greater risk in trading. In his assertions, Simon categorised emerging market into three phases; the most advanced markets, narrow emerging markets and emerging markets (latent).

Globalization is the means by which different economies or markets and societies become more closely integrated, and concurrent with increasing worldwide globalization. ${ }^{[18]}$. There is substantial evidence, from countries of different sizes and different regions, that as countries "globalize" their citizens benefit, in the form of access to a wider variety of goods and services, lower prices, more and better-paying jobs, improved health, and higher overall living standards. ${ }^{[14]}$.

Financial globalization resulted in the growth of international mutual funds. To the larger extent, this is an indication of the fact that investors in mature markets sought to diversify their assets by investing in emerging markets through dedicated emerging market fund i.e. invest exclusively in emerging markets or through increased emerging market participation by globally active funds ${ }^{[9]}$. Eichengreen and Mussa ${ }^{[5]}$, observed that the phenomenon has been propelled by technological change, privatization in emerging markets, the deregulation of the financial markets in industrial countries in the 1980s and early 1990s, increased in institutional investors in developed economies and macroeconomic and trade reforms have portrayed emerging markets more attractive ${ }^{[20]}$.

Investing in mutual funds is crucial in financial markets in emerging economies with underdeveloped capital markets and regular investors. Over the last decade, the global financial markets experienced a tremendous boost in the asset appreciation of mutual funds. In 2007 the mutual fund industry managed over \$26 trillion of financial assets including over $\$ 12$ trillion in stocks in contrast to the $\$ 6$ trillion of assets managed in $1996{ }^{[8]}$. Within the period there was a rocket growth in the numerical strength of mutual funds globally of over 66,000 funds of which nearly 27,000 were equity funds or approximately $40.91 \%$. There was a total of $\$ 40.4$ trillion above the total global mutual fund asset ${ }^{[16]}$. The emergence of mutual funds could be acclaimed to the United States which tremendously plays a vital role in stock markets. This trend replicates to other countries and economies in the world including emerging markets or economies ${ }^{[15]}$.

The financial sector has a vital task of supporting the economic activities of the underprivileged to enable them to carry on with their activities in the face of difficult challenges after the global economic crisis that occurred in $2008^{[26]}$. The financial system of a country widens in complexity, it behoves then on an individual to manage the financial details ${ }^{[13]}$. There is a need for people to manage their finances. The need for long-term investment, children's education and pension. Invariably, the decision to manage short-term savings, home acquisition and car loans amongst others. Health insurance, as well as personal insurance, are also issues of concern ${ }^{[1]}$.

The economic situation in most emerging or developing economies is an indication that the issue of personal financial planning is of concern. Most people have challenges to invest in financial assets, trade on the stock market or the financial market because they do not have adequate knowledge ${ }^{[13]}$. Meanwhile, financial literacy remains a major challenge in Ghana with the rate at which Ponzi schemes are sprouting up and swindling the masses. Dwiastant ${ }^{[3]}$, defines financial education as a chain of activities with long term tendency to quicken people to have financial goals and plans as well as to achieve prosperity in keeping with the lifestyle and pattern of life they want.

As a result of inadequate knowledge of the financial system, many potential investors suffered losses because of uncontrolled consumption, excessive, unnecessary spending and use of credit cards ${ }^{[17],[23]}$. Personal financial management is an individual's behavior to perform the planning, implementation, and evaluation of cash, credit, investment, insurance, life level and retirement ${ }^{[2]}$.

The global assets of mutual funds over the years depict their yielding potential in the long term. Sound financial knowledge is paramount to understanding personal financial management which entails the ability to plan one's finances and to achieve a fulfilled financial life ${ }^{[7]}$. An appreciable understanding of investment vehicles is therefore crucial in 
achieving personal financial goals. Mutual funds which are collective assets allow the common investor to invest in diversified portfolios that are professionally managed. Therefore, investing in mutual funds in emerging markets tend to create wealth and enhance personal financial liberation for the common investor.

\subsection{Varying scopes of emerging markets}

Globalization has enormous differing scopes that are distinct in fostering economic changes in emerging markets. These include but not limited to trade, foreign direct investments, short-term capital flows, knowledge and movements of labour. There have been positive paradigm shifts in emerging markets as they experience the waves of globalization.

\subsection{Short-term capital flows}

Funds movements across markets take dynamic forms: foreigners' direct investments in various economic sectors such as housing, education, manufacturing, and production among others. Sometimes, direct funds are invested in the construction of factories or portfolio investment. Short-term flows of portfolio investment include short-term lending whiles long-term flows include long-term bonds. However, each investment firm has its own merits and repercussions. As foreigners invest in the economy, technology and human capital are also exchanged which fosters positive economic strides. Predictions of foreign direct investments do not always yield the proposed results.

\subsection{Knowledge}

As barriers to communication and human movements become less rigid and more accessible, the flow of knowledge and ideas emerge very rampantly. Globalization has facilitated the transfer of knowledge which is likely to prove one of the strongest forces for growth in emerging markets ${ }^{[25]}$. Technical knowledge and ideas are globalized to transform societies. Democracy and market ideas form the core of emerging markets that enhance the adoption of policies and the functionality of institutions to boost economic performances.

\subsection{Movements of labour}

Globalization brings about fewer restrictions on trade barriers and the movement of people. Movements of labour especially from saturated economies to emerging markets as a result of foreign direct investments and new technological advancements have the potential to increase GDP. As investors from more developed countries are likely to import more experienced labour to less developed countries. Whiles these may increase the GDP of developing countries from the remittances of migrant labour, more developed countries are like to experience a rise in GDP. However, there are instances of brain drain where the outflow of young skilled workers has exploited a country of vital inputs for its economic growth.

\subsection{Trade}

Sachs \& Warner ${ }^{[22]}$, opined a positive relationship between trade and growth in their studies on the wealth of crosscountry, though some later studies cast reservations ${ }^{[4],[21]}$. It is believed that there are opportunities for countries that remove their trade barriers even if their partners do not reciprocate as disputed by standard theory. Developed countries mostly push unilateral trade liberalization on developing countries which do not often benefit their emerging economies. This has created avenues for the dumping of goods and products in most instances. The unfair trade agenda has resulted in liberalization directed at lowering global impediments to goods which are the developed countries' comparative advantage. This has resulted in sub-Sahara Africa, the poorest region in the world, actually being worse off at the end of the last round of trade liberalization ${ }^{[25]}$.

\section{The need for personal financial planning}

The economic impact of life cannot be overemphasized. The risk of injuries such as incapacitation or death may result in serious financial hardships to an individual's immediate dependents. There are various life goals such as education, buying a dream house, vacation and the kind of life one envisages in the future. Retirement is also a period that would require strong financial standing to meet the demands and challenges of old age. These warrant the importance of proper financial planning and security ${ }^{[7]}$.

\subsection{Diminishing nature of the human life value}

Fiergbor ${ }^{[7]}$, opined that the economic worth of an income earner tends to lessen with the passage of time or period. His or her earning potential may continue to upturn for a certain period or forever, but with each passing year, the outstanding period of income creation becomes smaller. Each year of income that is generated means that there is one year fewer that is left to be earned. Because a person's economic value is the unrealized earning capacity characterized by his or her expertise and skills, his or her fiscal value must lessen as potential income is transformed into real income.

This principle is demonstrated by the illustration in Figure 1 below. 
The line $\mathrm{AB}$ denotes the lifetime of a person born at point $\mathrm{A}$ and dying at point $\mathrm{B}$. Line $\mathrm{AB}$ also denotes the cost of upkeep and, during his or her prolific years, the individual's revenue tax liability. The arc CD denotes earning capability. During the era $\mathrm{A}$ to $\mathrm{C}$, there are no incomes, but there are costs of upkeep denoted by the triangle AEC. Incomes commence at $\mathrm{C}$. The region of arc $\mathrm{CD}$ that spreads above arc AB denotes earnings in surplus of taxes and the cost of self-upkeep. Point D symbolizes the age of retirement, and the region DFB represents the second major period.

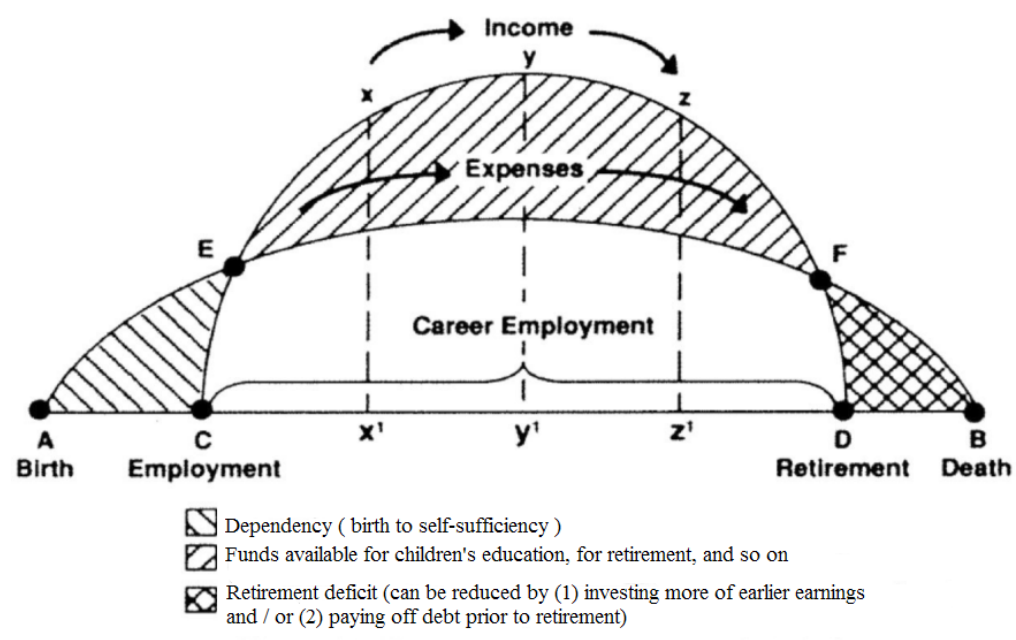

Figure 1. Hypothetical illustration of economic value of a human Life

In Figure 1 the economic value of a person is at its highest at point $E$ when net incomes are just commencing. At the point where $\mathrm{xx}^{1}$ interconnects the arcs, the incomes rate has increased, but possible future earnings have waned. The incomes potential shows further declines at $\mathrm{yy}^{1}$ as well as $\mathrm{zz}^{1}$; it then declines at point $\mathrm{F}$ to zero.

Neither income nor maintenance expenditures follow an equal curve. For instance, the childhood era starts with a highly uneven outlay for maternity expenditures. Income is also likely to begin prior than at point $\mathrm{C}$, and is doubtful, its likelihood to degenerate so steadily to the age of retirement.

In many professions, people reach their peak incomes in their 40s and 50s, and incomes increase or drop only marginally to retirement when they end abruptly.

\section{Mutual funds}

Mutual Funds are investment instruments that pool resources of like-minded investors into a common professionally managed portfolio intending to buy securities to create wealth for investors ${ }^{[6]}$. Mutual funds are flexible investment schemes that are made public to the general public and are also classified as open-ended. They provide investment schemes that are safe and lucrative. The combined securities of the mutual fund are known as a portfolio. Mutual funds are managed by professional fund managers, who invest the fund's money to create income and capital gains for the unit holders of the fund. Mutual funds allow investors to pool their investments together to participate in a larger and diversified portfolio ${ }^{[6]}$.

Mutual funds' investments avoid the usual restrictions on individual investments. This would increase their ability to diversify and lower the costs of buying and selling shares ${ }^{[6]}$. The proportion of tradable shares possession has inhibitory effect toward the rate of return as the current managerial fees and previous managerial fees affect the funding rate of return positively ${ }^{[27]}$. The profits of mutual funds usually consist of capital profits, profits resulting from improvement or change in the prices of the invested securities in addition to the securities distribution if any. The fund can face losses in case the value of the securities' that make up the fund's assets decreased.

Fiergbor ${ }^{[6]}$, opined that mutual funds managers diversify their activities in the following areas; Portfolio management services, Management of offshore funds, providing advice to offshore funds, management of pension or provident funds, management of venture capital funds, management of money market funds and management of real estate funds.

\subsection{Prospects of investing in mutual funds for personal financial planning}

A mutual fund serves as a link between the investor and the securities market by mobilizing savings from the investors and investing them in the securities market to generate returns. Money collected from investors is invested in diversified portfolios in the capital market and money market. Given this, each shareholder shares in the capital gains and capital 
losses in the fund. Simply put, mutual funds are a means of investing in something with a group of people ${ }^{[6]}$.

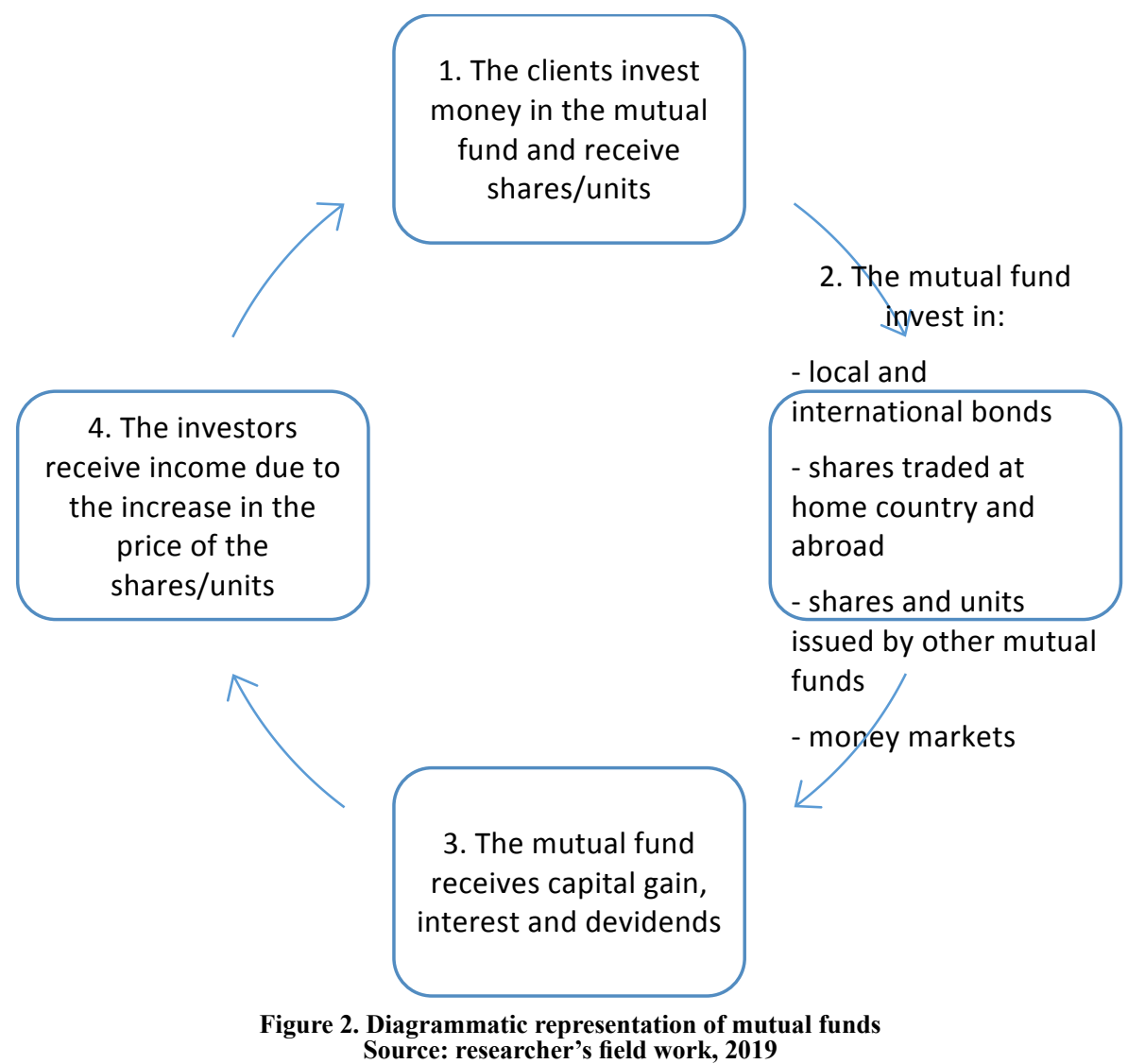

\subsection{Global distribution of mutual funds}

The collective investment schemes have a substantial share in the total volume of savings in the developed economies. Europe is the second-largest market in the world asset management industry and traditionally manages approximately onethird of the assets in the world. With is statistics, Africa which mostly comprises of several emerging markets have the potential of exploring more into mutual funds to create enabling environment for the lay investor.

\subsection{Investments returns on mutual funds}

Simple mathematical formula for calculating the future value of an investment was used to compute different present values for different investment years. The formulae are presented in equation (1) and (2) below. Random investment capitals were then computed over several investment years to forecast expected future yield. Investment capitals were randomly selected from $\$ 500.00$ to $\$ 100,000.00$ and maturity periods were also randomly selected from 1year to 30years. The results are represented in table 1 below. The expected monthly rates of returns are $2 \%$ accumulating a total annual rate of $24 \%$. Using the formulae below;

$$
\begin{aligned}
& F V=P V \cdot(1+i)^{n} \\
& F V=P V \cdot\left(1+\frac{i}{m}\right)^{\text {n.m }}
\end{aligned}
$$


Table 1. Projected returns on investment capitals over different periods

\begin{tabular}{ccccccccc}
\hline $\begin{array}{c}\text { Investment } \\
\text { Capital (\$) }\end{array}$ & $\mathbf{1}$ & $\mathbf{5}$ & $\mathbf{1 0}$ & $\mathbf{1 5}$ & $\mathbf{2 0}$ & $\mathbf{2 5}$ & $\mathbf{3 0}$ \\
\hline 500 & 643.12 & $1,640.52$ & $5,382.58$ & $17,660.42$ & $57,944.37$ & $190,117.25$ \\
1000 & $1,268.24$ & $3,281.03$ & $10,765.16$ & $35,320.83$ & $115,888.74$ & $380,234.51$ & $1,247,561.13$ \\
2000 & $2,536.48$ & $6,562.06$ & $21,530.33$ & $70,641.66$ & $231,777.47$ & $760,469.02$ & $2,495,122.26$ \\
5000 & $6,341.21$ & $16,405.15$ & $53,825.82$ & $176,604.16$ & $579,443.68$ & $1,901,172.54$ & $6,23,805.64$ \\
10000 & $12,682.42$ & $32,810.31$ & $107,651.63$ & $353,208.31$ & $1,158,887.35$ & $3,802,345.08$ & $12,475,611.28$ \\
50000 & $63,412.09$ & $164,051.54$ & $538,258.15$ & $1,766,041.57$ & $5,794,436.76$ & $19,011,725.40$ & $62,378,056.39$ \\
100000 & $126,842.18$ & $328,103.08$ & $1,076,516.30$ & $3,532,083.14$ & $11,588,873.52$ & $37,923,450.81$ & $124,756,112.77$ \\
\hline
\end{tabular}

Source: researcher's field work, 2019

\subsection{Advantages and disadvantages of investing in mutual funds}

The basic advantages in case of investing in mutual funds include the following; protection of the investors' interests, security, and transparency, possibility for the individual investor to gain access to the international markets, possibility for a high profitableness, possibility for small investments, economies of scale - the investment company diversification where the expenses on 1 monetary unit investment are lower and professional fund management.

Having in mind the above-mentioned advantages, it is necessary to outline their disadvantages and namely: buying and selling units take time and the profitability is not guaranteed.

\section{Conclusion}

Globalization has rendered emerging market porous to foreign investors as there are imaginary foreign investment and trade restrictions. As a result, emerging markets are viable investment avenues for long term financial returns as such markets are plagued with huge untapped potentials. Emerging markets in Africa have higher potentials of attracting investors due to the abundance of natural resources and the openness of such markets to foreign investors. Markets such as Ghana have huge potentials for expansion and growth as oil discovery and exploration are on the rise. As the economies become more opened and investment in other sectors booms, there is a higher probability of upward economic performances which would trigger the need for financial leverage for the lay investor. Mutual funds are ideal investment avenues for personal financial planning as they are characterised by low risk, professionally managed service, low investment capital and a higher probability of returns. However, it is more difficult for the ordinary investor to understand the activity of the mutual funds because an increase in financial knowledge is needed. Proper understanding and investment in mutual funds will yield good future returns over a period of time and as result endure financial independence. They are therefore good investment avenues for the common investor and to help plan ones finances.

\section{Conflicts of interest}

There was no conflict of interest encountered in the course of this study.

\section{Acknowledgments}

I am grateful to Prof. Michael Kwateng for his enormous support in my academic life.

\section{References}

[1] Annamaria, L., Mitchell, O.S. Financial literacy around the world: An overview. Journal of Pension Economics and Finance. 2011; 210(4): 1-10.

[2] Chen, H. An analysis of personal financial literacy among college students. Financial Services Review. 1998; 7(2):107-128.

[3] Dwiastanti, A. Financial literacy as the foundation for individual financial behavior. Journal of Education and Practice. 2015; 6(33): 99-105.

[4] Easterly, W. Good policy or good luck? Country growth performance and temporary shocks. National Bureau of Economic Research Working Paper No. 4474. 1993.

[5] Eichengreen Barry and Michael Mussa. Capital Account Liberalization: Theoretical and Practical Aspects. Occasional Paper No. 170 (Washington: International Monetary Fund). 1998.

[6] Fiergbor D.D. Blockchain Technology in Fund Management. In: Deka G., Kaiwartya O., Vashisth P., Rathee P. (eds) 
Applications of Computing and Communication Technologies. ICACCT 2018. Communications in Computer and Information Science. 2018; 899. Springer, Singapore.

[7] Fiergbor, D. D. Life Insurance as a Social Security Mechanism. ADRRI Journal of Arts and Social Sciences. Ghana. 2019; 16(9): 47-58, E-ISSN: 2343-6891, $31^{\text {st }}$ May, 2019.

[8] Ferreira, A. M., Miguel, F. A. The Determinants of Mutual fund Performance: A Cross-Country Study. www.ssrn.com. 2009.

[9] Gaston Gelos . International Mutual Funds, Capital Flow Volatility, and Contagion-A Survey. Encyclopedia of Financial Globalization. 2011. Elsevier.

[10] Greenspan, A. The Importance of Financial Education Today. Social Education. 2005; 69(2): 64-65.

[11] Hall, A. D.. Getting Started in Mutual funds, 2nd Ed.. Hoboken, NJ: John Wiley \&Sons Inc.. 2010.

[12] Hilgert, A. M. Hogarth, J. M. Household Financial Management: The Connection. 2002.

[13] Irma S., and Sugeng S. Does the Sharia Personal Financial Management Require? Study of Sharia Financial Literacy among Lecturers. International Journal of Economics and Financial Issues; 2017, 7(4): 411-417.

[14] IMF. Globalization: A Brief Overview, Issues Briefs, IMF Publication Services, Issue 02/08 http://www.imf.org. 2008.

[15] Khorana, A., Servaes, H., and Tufano, P. Explaining the size of the mutual fund industry around the world. Journal of Financial Economics. 2005; 78: 145-185.

[16] Kong, Y., Owusu-Akomeah, M., Antwi, H.A., et al. Evaluation of the robusticity of mutual fund performance in Ghana using Enhanced Resilient Backpropagation Neural Network (ERBPNN) and Fast Adaptive Neural Network Classifier (FANNC). Financ Innov. 2019; 5: 10. https://doi.org/10.1186/s40854-019-0125-5.

[17] Nidar, S.R., Bestari, S. Personal financial literacy among university students (case study at Padjadjaran university students, Bandung, Indonesia). World Journal of Social Sciences. 2012; 2(4): 162-171.

[18] Nilson, Theresse. Good for Living? On the Relationship between Globalization and Life Expectancy. World Development. 2010; 38(9): 1191-1203.

[19] Northcott, A.. The Mutual Funds Book: How to invest in mutual funds \&Earn higher rates of returns. Ocala, FL: Atlantic Publishing Group, Inc. 2009.

[20] Pasquariello, Paolo. Imperfect Competition, Information Heterogeneity, and Financial Contagion. Review of Financial Studies. 2006; 20(2): 391-426.

[21] Rodrik, D., \& Rodriguez, A. Trade policy and economic growth: A skeptic's guide to the cross-national evidence. Centre for Economic Policy Research Discussion Paper: 1999; 2143.

[22] Sachs, J., \& Warner, A. The big push natural resource booms and growth. Journal of Development Economics. 1999; 59(1): 43-76.

[23] Setyawati, I., Suroso, S. Sharia financial literacy and effect on social economic factors (survey on lecturer in Indonesia). International Journal of Scientific and Technology Research. 2016; 5(2): 92-102.

[24] Simon, Y. Encyclopedie des marches financiers. Paris: Editura Economica. 1997.

[25] Stiglitz, J. Trade and the developing world: A new agenda. Current History. 1999; 98(631): 387-393.

[26] Tsomocos, D.P. Equilibrium Analysis, Banking, Contagion, and Financial Fragility (No.175). London. Available from: http://www.eprints.lse.ac.uk/24826/1/dp450.pdf. 2003.

[27] Yi, J., Lu, D., \& Deng, Y. Empirical Study under the Encouraging Model to Managerial Fees of Social Security Fund Investment. American Journal of Industrial and Business Management. 2016; 6(05): 649 